\title{
The Attenuation Characteristics of the Body Tissue on Frequency Function in WBAN Channel
}

\author{
Achmad Mauludiyanto \\ Department of Electrical Engineering \\ Institut Teknologi Sepuluh Nopember \\ Surabaya, Indonesia \\ maulud@ee.its.ac.id
}

\author{
Gamantyo Hendrantoro \\ Department of Electrical Engineering \\ Institut Teknologi Sepuluh Nopember \\ Surabaya, Indonesia \\ gamantyo@ee.its.ac.id
}

\author{
Muhammad Fachry Nova \\ Department of Electrical Engineering \\ Institut Teknologi Sepuluh Nopember \\ Surabaya, Indonesia \\ fachrynova@gmail.com
}

\begin{abstract}
The Wireless Body Area Network (WBAN) refers to a communication network between sensors placed on the inside, on the surface, or around the body wirelessly. WBAN system cannot be separated from body tissues. Body tissues also have electrical properties depending on frequency. Therefore, body tissue can affect the phenomena occurring in radio wave propagation in the WBAN channel. One of the phenomena is attenuation. This study investigates the impacts of body tissue on the WBAN channel and the effects of frequency on the attenuation of body tissue in the WBAN channel. The measurement of magnitude response was carried out with the human body as the measurement object by utilizing the $\mathbf{S 2 1}$ parameter measurement with a vector network analyzer. In NLOS conditions, a human body was located between two coplanar Vivaldi antenna. Measurements were conducted on the head, chest, and abdomen. The frequency used was in the range of $2 \mathrm{GHz}$ to $6 \mathrm{GHz}$. The body tissue attenuation was obtained by finding the difference between the magnitude measurement response on the LOS and NLOS conditions. The attenuation data were analyzed using statistical and numerical analysis to determine the effect of frequency on the attenuation of the human body tissues. Based on the analysis results, it was identified that the frequency affected the human body tissue attenuation. The enhancement attenuation of the human body tissues occurred when the frequency was higher. Moreover, there was a significant difference in the body tissue attenuation in different parts of the body.
\end{abstract}

Keywords - attenuation, body tissues, s-parameters, wireless body area network.

\section{INTRODUCTION}

In recent years, Wireless Body Area Networks (WBAN) has attracted considerable attention due to its extensive application. WBAN can be applied in various fields, such as health, military and defense, and entertainment [1] [2]. Three types of WBAN communication include in-body, on-body, and off-body. In-body WBAN refers to the sensor which is put inside the body. On-body indicates the sensor placed on the body surface. Furthermore, off-body is when the sensor is positioned in the area around the body. In-body is when the sensor is put inside the body [2]. Based on WBAN communication types, the radio wave propagation of WBAN can not be separated from the effects of human body tissues. Based on standard IEEE 802.15.6, three types of wireless communication technology can be utilized in the WBAN system, among others, Human Body Communication (HBC), Narrowband (NB), and Ultra-wideband (UWB). The three technologies have different channel parameters, one of which is the frequency band [3]. The frequency difference can affect the phenomenon of radio wave propagation; one of them is the attenuation. This study investigates the effects of the frequency on the human body tissue attenuation in the frequency range 2-6 GHz.

\section{METHODS}

\section{A. Literature Review}

1) Wireless Body Area Network

The wireless body network area or Body Area Network (BAN) consists of a heterogeneous set node that can sense, move, calculate, and communicate through the multi-hop wireless channel. If the BAN is installed wirelessly, the network is referred to as the Wireless Body Area Network (WBAN) [4]. There are three physical layers mentioned in the IEEE 802.15.6 for WBAN, i.e., Human Body Communication (HBC), Narrowband (NB), and Ultrawideband (UWB). The use of HBC is different from NB and UWB, where the HBC only using the human body as the medium of wave propagation. The NB and UWB frequency allocation can be seen in the following figure [3] [5]:

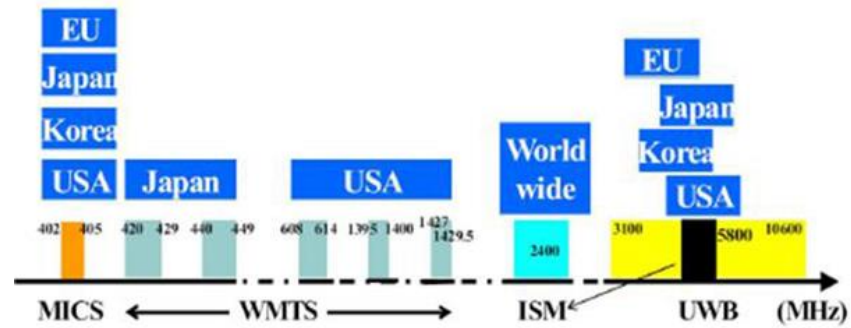

Fig. 1. Frequency bands of WBAN [3][5]

\section{2) The Electrical Nature of Body Tissue}

The human body is not an ideal medium for radio wave propagation. The electrical nature of human body tissue changes by the frequency. It is indicated by the change of conductivity and permittivity along with the frequency change. The frequency change is divided into three area dispersions, denoted by the dispersion area of $\alpha, \beta$, and $\gamma$. The dispersion area signifies the behavior of the body tissues changes to the frequency change. The electrical nature of human's body tissue is shown by Figure 2 as follows [6][7]: 


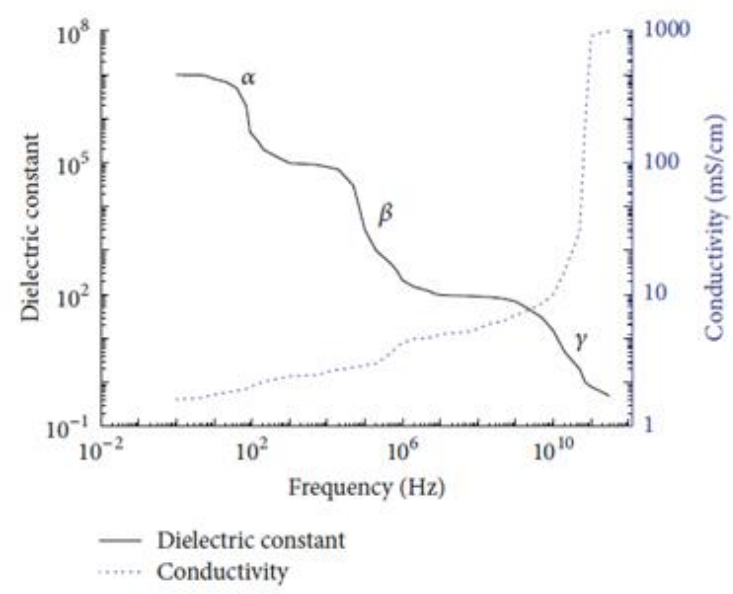

Fig. 2. The conductivity chart and the dielectric constant of body tissue [6][7].

1. the $\alpha$-dispersion (low $\mathrm{kHz}$ )

This area has a high value of permittivity and low value of conductivity.

2. $\beta$-dispersion (0.1-10 MHz)

In this area, relaxation effects occur. The load addition on the cell membrane through intracellular and extracellular are easier. The current can flow through the intracellular and extracellular medium, so the conductivity is increased.

\section{3. the $\gamma$-dispersion $(>1 \mathrm{GHz})$}

This area is a high conductivity area caused by several networks, such as amino acid, nucleic, and protein solution.

\section{3) Attenuation}

Attenuation is energy reduction. When the signal passes through a medium, the signal will lose some of the energy. The decibel concept $(\mathrm{dB})$ is to indicate whether the signal has lost or added its strength. Decibel $(\mathrm{dB})$ measures the relative strength of two signals or a signal at two different points. If the decibel value is negative, the attenuation on the signal occurs. Meanwhile, if the decibel value is positive, the signal's strengthening is indicated [8]. The equation of the decibel concept is as follows:

$d B=10 \log _{10}\left(\frac{P_{2}}{P_{1}}\right)$

where;

$\mathrm{P}_{1}$ : the signal power at point $1(\mathrm{~W})$

$\mathrm{P}_{2}$ : the signal power at point $2(\mathrm{~W})$

\section{4) Skin Depth}

Skin depth indicates how deep an electromagnetic wave can penetrate the conductive medium. The skin depth equation is as follows [9] [10]:

$$
\delta=\left(\pi f \mu \sigma_{\text {cond }}\right)^{-\frac{1}{2}}
$$

where;

$$
\begin{array}{ll}
\delta & : \text { Skin depth }(\mathrm{m}) \\
\mathrm{f} & : \text { frequency }(\mathrm{Hz}) \\
\mu & : \text { Permeability } \\
\sigma_{\text {cond }} & : \text { conductivity }(\mathrm{S} / \mathrm{m})
\end{array}
$$

\section{5) Scattering Parameters}

Scattering parameters or S-parameters are a scale that expresses the relationship between a port or terminal on a transmission line where there is a signal on the transmission line transmitted and reflected. S-parameters on the two-port network shown in the Figure 3 as follows [9]:

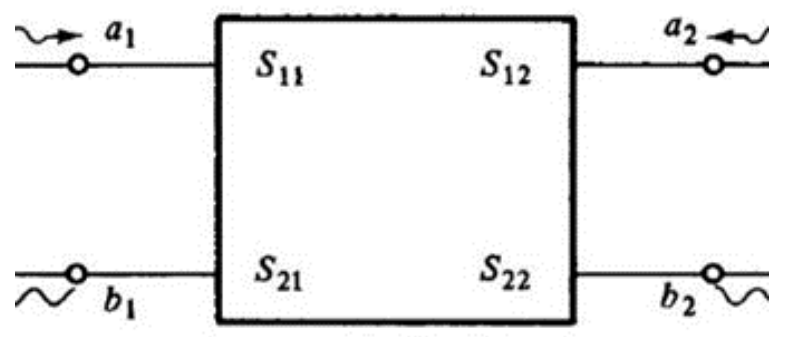

Fig. 3. Scattering parameters on the two-port network [9]

\section{6) Linear Regression}

Regression analysis is a statistical technique to figure out and model the relationship between variables. The linear regression model is a model with the single $(\overline{\mathrm{x}})$ regressor/predictor, which has a connection with the response $(\hat{y})$, which is a straight line [10]. The following equation signifies the linear regression model:

$\hat{y}=\widehat{\beta}_{0}+\widehat{\beta}_{1} x$

$\widehat{\beta}_{1}$ is obtained in the following equation:

$\hat{\beta}_{1}=\frac{\sum_{\mathrm{i}=1}^{\mathrm{n}} \mathrm{y}_{\mathrm{i}} \mathrm{x}_{\mathrm{i}}-\frac{\left(\sum_{\mathrm{i}=1}^{\mathrm{n}} \mathrm{y}_{\mathrm{i}}\right)\left(\sum_{\mathrm{i}=1}^{\mathrm{n}} \mathrm{x}_{\mathrm{i}}\right)}{\mathrm{n}}}{\sum_{\mathrm{i}=1}^{\mathrm{n}} \mathrm{x}_{\mathrm{i}}^{2}-\frac{\left(\sum_{\mathrm{i}=1}^{\mathrm{n}} \mathrm{x}_{\mathrm{i}}\right)^{2}}{\mathrm{n}}}$

$\widehat{\beta}_{0}$ is obtained in the following equation:

$\widehat{\beta}_{0}=\overline{\mathrm{y}}-\widehat{\beta}_{1} \overline{\mathrm{x}}$

where,

$\overline{\mathrm{y}}=\frac{1}{\mathrm{n}} \sum_{\mathrm{i}=1}^{\mathrm{n}} \mathrm{y}_{\mathrm{i}}$

$\overline{\mathrm{x}}=\frac{1}{\mathrm{n}} \sum_{\mathrm{i}=1}^{\mathrm{n}} \mathrm{x}_{\mathrm{i}}$

\section{Descriptions:}

$\mathrm{x}_{\mathrm{i}}$ : the independent variable of observation results

$\mathrm{y}_{\mathrm{i}}$ : the dependent variable of observation results

$\bar{y} \quad$ : the average dependent variable of observation results

$\overline{\mathrm{x}}$ : the average independent variable of observation results

$\mathrm{n}$ : the number of observation result data

$\widehat{\beta}_{0}:$ intercept

$\widehat{\beta}_{1}:$ slope

$\mathrm{X}$ : regressor/predictor

$\hat{\mathrm{y}} \quad$ : response variable

\section{B. MEASUREMENT}

\section{1) Measurement Scenario}

In this study, the response magnitude measurement was carried out using the vector network analyzer (VNA) in the 
frequency range 2-6 GHz. The measurement was conducted with a body measurement scenario to the head, chest, and abdomen with two-track conditions, i.e., the line of sight (LOS) and non-line of sight (NLOS) conditions. In the LOS condition, two antennas were connected on port VNA facing each other without locating the human body between the two antennas. In contrast, in the NLOS condition, a human body was located between the two antennas. The distance between the antenna with the human body was based on the distance calculation of the far-field region of an antenna. The antenna utilized was a UWB coplanar Vivaldi antenna with working frequency 2-10 GHz. The dimension of this antenna was $6 \mathrm{~cm}$. Based on the calculation, the distance of the far-field region of the antenna on $6 \mathrm{GHz}$ frequency reached $14.4 \mathrm{~cm}$. The scenario measurements in LOS and NLOS conditions can be seen in Figures 4 and 5.

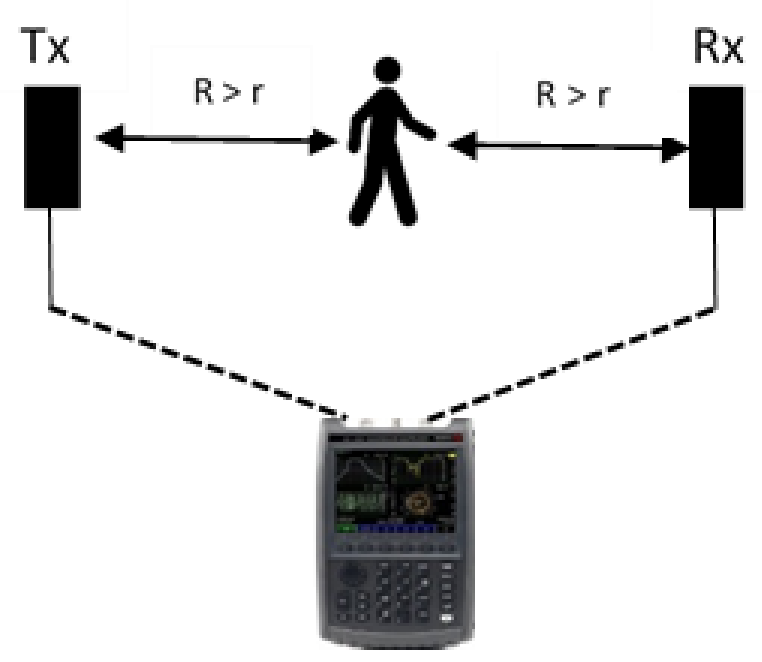

Fig. 4. The measurement in NLOS condition

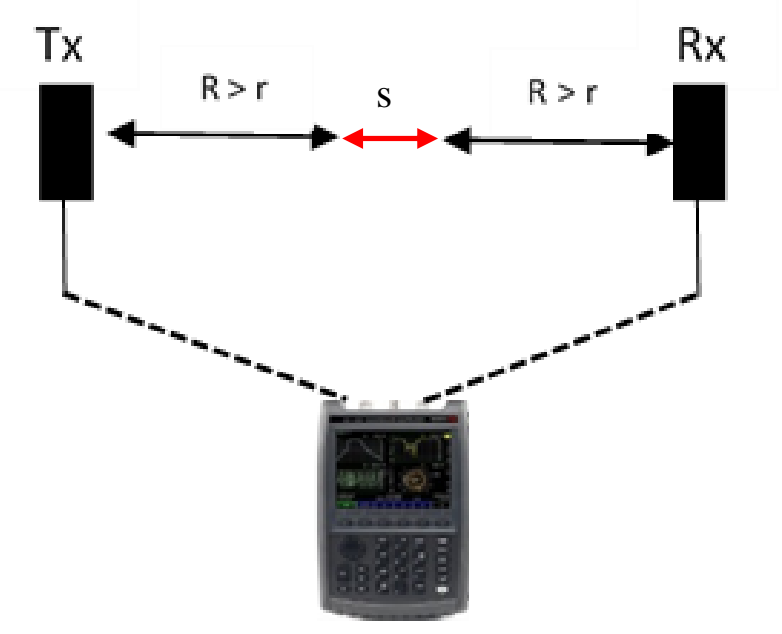

Fig. 5. The measurement of the LOS condition

\section{Descriptions:}

Tx : transmitter antenna

$\mathrm{Rx}$ : receiver antenna

$\mathrm{r}$ : far-field distance

$\mathrm{R}$ : the distance measurement

s : the body parts thickness
Meanwhile, the scenario measurement is described in Table 1.

TABLE I. MEASUREMENT SCENARIO

\begin{tabular}{|l|l|l|}
\hline Antenna Position & Track Conditions & $\begin{array}{l}\text { Measurement } \\
\text { Frequency }\end{array}$ \\
\hline \multirow{2}{*}{ Head } & LOS & Ten times \\
\cline { 2 - 3 } & NLOS & Ten times \\
\hline \multirow{2}{*}{ Chest } & LOS & Ten times \\
\cline { 2 - 3 } & NLOS & Ten times \\
\hline Abdomen & LOS & Ten times \\
\cline { 2 - 3 } & NLOS & Ten times \\
\hline
\end{tabular}

2) Head Measurement

In the measurement of the head as shown in Figure 6, the two antennas were faced with the same height according to the height of the person's head measured in both LOS and NLOS conditions. In NLOS conditions, the antennas were confronted with each other where there was a person's head measured between the two antennas, while in LOS conditions, there was no person's head. Considering the long-field distance of the antenna, the distance between the antenna and the body was $20 \mathrm{~cm}$, the height of the two antennas from the ground also adjusted each person's height.

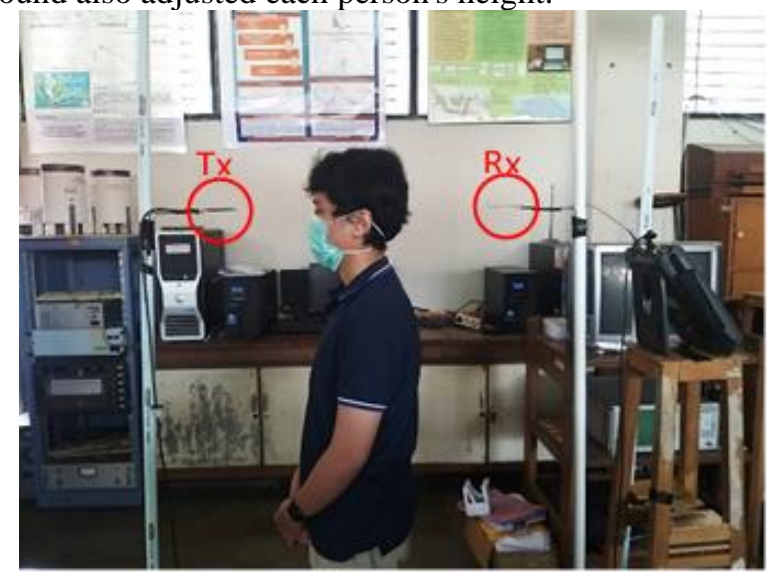

Fig. 6. Head Measurement

\section{3) Chest Measurement}

In the measurement of the chest as shown in Figure 7, the two antennas were faced with each other at the height according to the person's chest height being measured. In the NLOS condition, the antenna was confronted with each other with a person's chest being measured between the two antennas, while in the LOS condition, it did not apply. The distance between the antenna and the chest amounted to $20 \mathrm{~cm}$. The height of the chest was adjusted to the height of the person's chest from the floor.

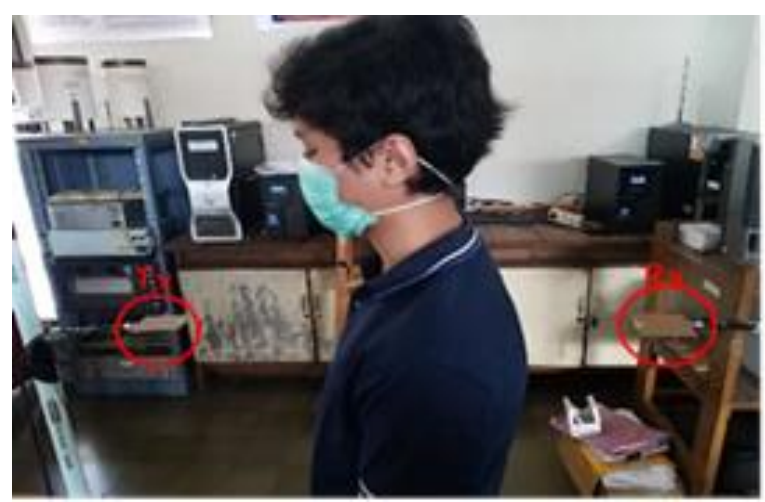

Fig. 7. Chest measurement 


\section{4) Abdomen Measurement}

In the measurement of the abdomen as shown in Figure 8, the two antennas were faced with each other according to the person's abdomen's height being measured. Measurements were carried out both in LOS and NLOS conditions, such as in the measurement of the head and chest, where, in the NLOS conditions, there was a person's abdomen being measured between the two antennas. The distance between the antennas to the abdomen was $20 \mathrm{~cm}$, with the height adjusted for the person's height.

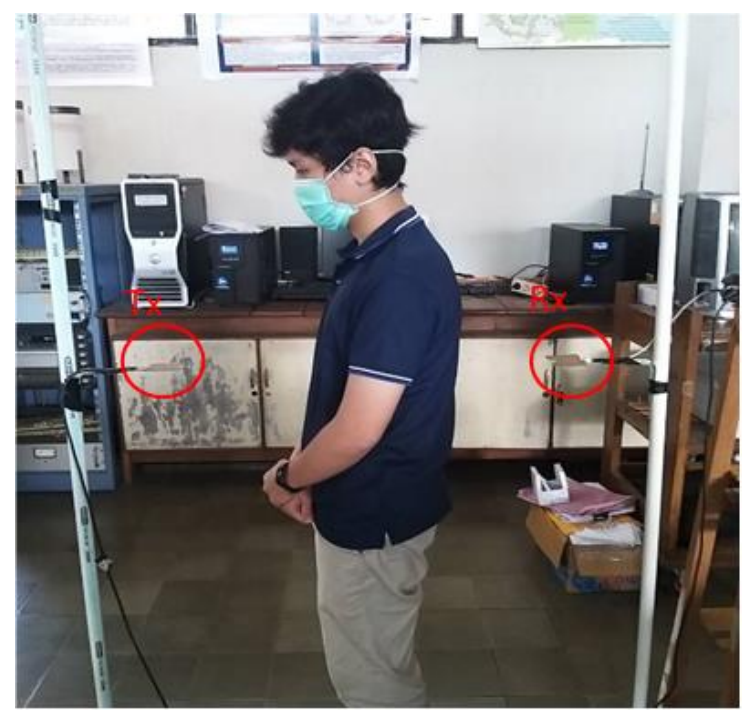

Fig. 8. Abdomen Measurement

\section{5) Magnitude Response Measurement}

To obtain the magnitude response, the measurement scenario was conducted by using the measurement of the $S_{21}$ parameter magnitude on the VNA. The $S_{21}$ data from VNA indicated the difference in power received at the two ports on a logarithmic scale $(\mathrm{dB})$. To obtain the attenuation data of body tissue, it can be discovered by the equation:

$$
A(d B)=S_{21} \operatorname{LOS}(d B)-S_{21} N L O S(d B)
$$

where;

A

$\mathrm{S}_{21}$ NLOS

: The Attenuation of Body Tissues

$\mathrm{S}_{21} \operatorname{LOS}$

: The Measurement of $S_{21}$ Magnitude with NLOS $(\mathrm{dB})$ conditions

$\mathrm{S}_{21} \mathrm{LOS}$

$$
\begin{aligned}
& \text { The Measurement of } \mathrm{S}_{21} \text { Magnitude with } \\
& \text { LOS }(\mathrm{dB}) \text { conditions }
\end{aligned}
$$

Data collection was carried out ten times for each measurement so that there were ten attenuation data for each part of the body. The average of all the data was then calculated to obtain the average attenuation for each part of each person. After the attenuation data of the body tissues were obtained, it was then continued with data analysis. A linear regression analysis was performed to discover how the characteristics of the attenuation of the body tissues toward the frequency function.

\section{RESULTS AND DISCUSSIONS}

\section{A. Linear Regression Results}

The linear regression technique was carried out on each attenuation data for each part of the body of each person. The linear regression results are revealed in Table 2.
TABLE II. LINEAR REGRESSION RESULTS

\begin{tabular}{|l|l|l|l|l|l|l|l|l|l|}
\multicolumn{8}{|c|}{ Table of Linear Regression Equations $(\mathbf{y}=\mathbf{a}+\mathbf{b x}) ; \mathbf{y}=\mathbf{d B} ; \mathbf{x}=\mathbf{G H z}$} \\
RMS error $=\mathbf{d B}$
\end{tabular}

The table above shows the equation of the regression curve for each part of the body for each person, where a indicates the constant or intercept, while $b$ indicates the regression coefficient or slope. The slope revealed how the contribution of variable changes on the $\mathrm{x}$-axis, in this case, was the frequency against the $y$-axis, which indicated the attenuation of body tissue. All slope values in the table suggested a positive value, where a positive slope showed that the curve had an increasing trend as the $\mathrm{x}$-axis variable increases. In this case, the equation of the linear regression model for the attenuation of body tissues in all parts of the body revealed that the attenuation of body tissues increased with increasing frequency.

An example of a regression graph as shown in Figure 9, which shows the results of the data regression measurement of head attenuation in person $\mathrm{A}$. In the same way, the regression results are obtained in other parts of the body and different people as shown in Table 2. As an additional condition, this regression applies only to $2050<\mathrm{f}(\mathrm{GHz})<5950$.

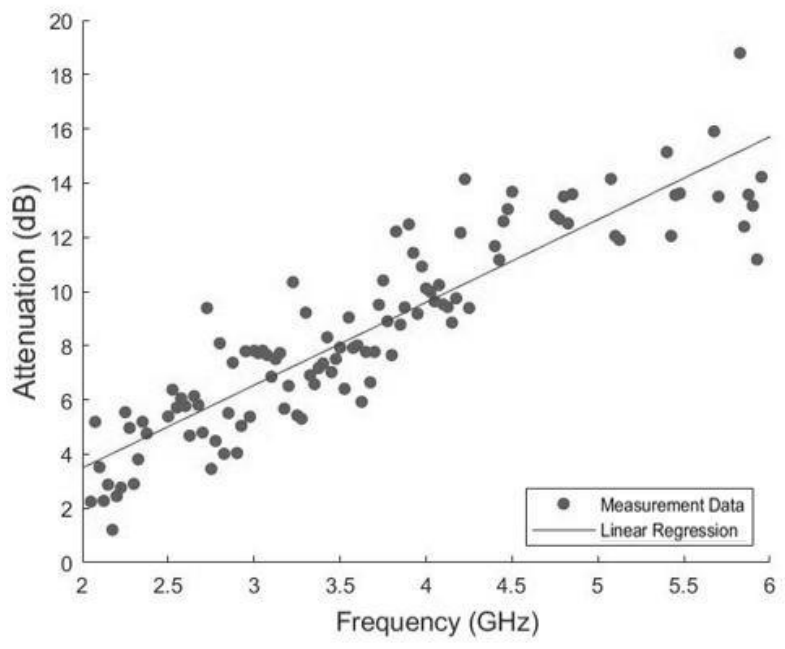

Fig. 9. Graph of the regression data for attenuation measurements in person A's head.

\section{B. Hypothesis Testing}

Hypothesis testing was conducted to determine whether the regression coefficient that had been obtained was significant or not. The hypothesis proposed is:

$$
\begin{aligned}
& \mathrm{H}_{0}: \mathrm{b}=0 \\
& \mathrm{H}_{\mathrm{a}}: \mathrm{b} \neq 0
\end{aligned}
$$

The value of $b$ in $\mathrm{H}_{0}$ as the regression coefficient in the linear regression equation that had been previously obtained was equal to zero, which means that there was no effect of frequency on the attenuation of body tissues, while $\mathrm{H}_{\mathrm{a}}$, namely $\mathrm{b}$, was not equal to zero, which means that there was an effect of frequency on the attenuation of body tissues. To discover the significance of the coefficient b, a T-test and a search for 
the P-value was carried out on the coefficient with a significance level of 5\%. Then a model test was conducted to determine how strong the effect of frequency on the attenuation of body tissue by seeking the coefficient of determination $\left(\mathrm{R}^{2}\right)$.

TABLE III. HYPOTHESIS TEST PARAMETERS ON THE HEAD

\begin{tabular}{|l|l|l|l|l|}
\hline \multicolumn{5}{|c|}{ Head } \\
\cline { 3 - 5 } \multicolumn{1}{|c|}{ Testing } & \multirow{2}{*}{ Parameters } & \multicolumn{1}{c|}{$\boldsymbol{A}$} & \multicolumn{1}{c|}{$\boldsymbol{B}$} & \multicolumn{1}{c|}{$\boldsymbol{C}$} \\
\hline \multirow{2}{*}{$\begin{array}{l}\text { Coefficient } \\
\text { test b }\end{array}$} & T Value & 21.859 & 13.841 & 9.6003 \\
\cline { 2 - 5 } & P Value & $1.87 \mathrm{E}-41$ & $1.13 \mathrm{E}-25$ & $3.78 \mathrm{E}-16$ \\
\hline Model test & R squared & 0.816 & 0.639 & 0.46 \\
\hline
\end{tabular}

TABLE IV. HYPOTHESIS TEST PARAMETERS ON THE CHEST

\begin{tabular}{|l|l|l|l|l|}
\hline \multicolumn{5}{|c|}{ Head } \\
\hline \multirow{2}{*}{ Testing } & \multirow{2}{*}{ Parameters } & \multicolumn{1}{c|}{ People } \\
\cline { 3 - 5 } & & \multicolumn{1}{c|}{$\boldsymbol{A}$} & \multicolumn{1}{c|}{$\boldsymbol{B}$} \\
\hline $\begin{array}{l}\text { Coefficient } \\
\text { test b }\end{array}$ & T Value & 4.3251 & 4.1694 & 2.7622 \\
\cline { 2 - 5 } & P Value & $3.41 \mathrm{E}-05$ & $6.19 \mathrm{E}-05$ & $6.75 \mathrm{E}-03$ \\
\hline Model test & R squared & 0.148 & 0.139 & 0.066 \\
\hline
\end{tabular}

TABLE V. HYPOTHESIS TEST PARAMETERS ON THE ABDOMEN

\begin{tabular}{|l|l|l|l|l|}
\hline \multirow{2}{*}{ Testing } & \multirow{2}{*}{ Parameters } & \multicolumn{1}{|c|}{ Head } \\
\cline { 3 - 5 } & & \multicolumn{1}{|c|}{$\boldsymbol{A}$} & \multicolumn{1}{c|}{$\boldsymbol{B}$} & $\boldsymbol{C}$ \\
\hline \multirow{2}{*}{$\begin{array}{l}\text { Coefficient } \\
\text { test b }\end{array}$} & T Value & 6.1641 & 2.9019 & 4.7998 \\
\cline { 2 - 5 } & P Value & $1.25 \mathrm{E}-08$ & $4.50 \mathrm{E}-03$ & $5.13 \mathrm{E}-06$ \\
\hline Model test & R squared & 0.26 & 0.0723 & 0.176 \\
\hline
\end{tabular}

\section{The attenuation of body tissues}

This section revealed the amount of attenuation of body tissue at a specific frequency with a bandwidth by utilizing a statistical parameter, namely the average. The amount of attenuation calculated was the average attenuation at a frequency as the middle frequency $\left(f_{c}\right)$, assuming it had a bandwidth of $50 \mathrm{MHz}\left(\mathrm{f}_{\mathrm{c}} \pm 25 \mathrm{MHz}\right)$. This revealed how much attenuation occurred when the signal sent was the result of modulation. The $50 \mathrm{MHz}$ bandwidth selection referred to the standard from the ECC (Electronic Communications Committee), namely ECC/DEC/(06)04, regarding the application of UWB (ultra-wideband) technology. UWB technology is a technology that can be used in wireless body area network systems. The standard states that the minimum bandwidth of devices with UWB technology is $50 \mathrm{MHz}$. The standard also sets a limit on the maximum transmitted signal power defined in the width of $50 \mathrm{MHz}$.

TABLE VI. ATTENUATION OF BODY TISSUES

\begin{tabular}{|c|c|c|c|c|c|c|c|c|c|}
\hline \multicolumn{10}{|c|}{ Attenuation at each Frequency with a Bandwidth of $50 \mathrm{MHz}$ (dB) } \\
\hline & \multicolumn{3}{|l|}{$\boldsymbol{A}$} & \multicolumn{3}{|l|}{$\boldsymbol{B}$} & \multicolumn{3}{|l|}{$C$} \\
\hline & $\begin{array}{l}2275 \\
\mathrm{MHz}\end{array}$ & $\begin{array}{l}3150 \\
\mathrm{MHz}\end{array}$ & $\begin{array}{l}5100 \\
\mathrm{MHz}\end{array}$ & $\begin{array}{l}2275 \\
\mathrm{MHz}\end{array}$ & $\begin{array}{l}3150 \\
\mathrm{MHz}\end{array}$ & $\begin{array}{l}5100 \\
\mathrm{MHz}\end{array}$ & $\begin{array}{l}2275 \\
\mathrm{MHz}\end{array}$ & $\begin{array}{l}3150 \\
\mathrm{MHz}\end{array}$ & $\begin{array}{l}5100 \\
\mathrm{MHz}\end{array}$ \\
\hline Head & 4,47 & 6,97 & 12,70 & 3,66 & 5,53 & 8,61 & 5,32 & 7,02 & 10,88 \\
\hline Chest & 16,63 & 16,93 & 22,11 & 15,48 & 25,69 & 26,33 & 15,14 & 28,41 & 28,60 \\
\hline $\begin{array}{l}\text { Ab- } \\
\text { do- } \\
\text { men }\end{array}$ & 16,88 & 23,22 & 29,34 & 17,13 & 19,43 & 20,18 & 14,70 & 23,13 & 26,95 \\
\hline
\end{tabular}

Table 6 shows how much attenuation is based on the measurement results at frequencies around $2 \mathrm{GHz}, 3 \mathrm{GHz}$, and $5 \mathrm{GHz}$. There were three middle frequencies selected, i.e., 2.275 GHz, 3.15 GHz, and 5.1 GHz. These three frequencies were selected with the consideration that the two antennas had the best VSWR in the measurement process (close to 1) at the three frequencies. From the table, it is evident that there is an increase in attenuation at higher frequencies.

From the link budget calculation, it was obtained the calculation of the attenuation of the body tissue measurement results. The comparison of attenuation values is shown in Table 7, 8, and 9.

TABLE VII. COMPARISON OF ATTENUATION BODY A MEASUREMENTS WITH CALCULATIONS

\begin{tabular}{|c|c|c|c|c|c|c|}
\hline \multicolumn{7}{|c|}{ Body Attenuation A (dB) } \\
\hline & \multicolumn{2}{|c|}{$2275 \mathrm{MHz}$} & \multicolumn{2}{|c|}{$3150 \mathrm{MHz}$} & \multicolumn{2}{|c|}{$5100 \mathrm{MHz}$} \\
\hline & \begin{tabular}{|l|}
$\begin{array}{l}\text { Measure- } \\
\text { ment }\end{array}$ \\
\end{tabular} & \begin{tabular}{|l}
$\begin{array}{l}\text { Calcula- } \\
\text { tion }\end{array}$ \\
\end{tabular} & \begin{tabular}{|l} 
Measure- \\
ment
\end{tabular} & $\begin{array}{l}\text { Calcula- } \\
\text { tion }\end{array}$ & $\begin{array}{l}\text { Measure- } \\
\text { ment }\end{array}$ & \begin{tabular}{|l|}
$\begin{array}{l}\text { Calcula- } \\
\text { tion }\end{array}$ \\
\end{tabular} \\
\hline Head & 4.47 & 3.429703 & 6.97 & 7.32 & 12.70 & 13.58477 \\
\hline Chest & 16.63 & 16.77884 & 16.93 & 18.31 & 22.11 & 23.10845 \\
\hline Abdomen & 16.88 & 16.33 & 23.22 & 24.94 & 29.34 & 30.52 \\
\hline
\end{tabular}

TABLE VIII. COMPARISON OF ATTENUATION BODY B MEASUREMENTS WITH CALCULATIONS

\begin{tabular}{|c|c|c|c|c|c|c|}
\hline \multicolumn{7}{|c|}{ Body Attenuation B (dB) } \\
\hline & \multicolumn{2}{|c|}{$2275 \mathrm{MHz}$} & \multicolumn{2}{|c|}{$3150 \mathrm{MHz}$} & \multicolumn{2}{|c|}{$5100 \mathrm{MHz}$} \\
\hline & $\begin{array}{l}\text { Measure- } \\
\text { ment }\end{array}$ & $\begin{array}{l}\text { Calcula- } \\
\text { tion }\end{array}$ & $\begin{array}{l}\text { Measure- } \\
\text { ment }\end{array}$ & $\begin{array}{l}\text { Calcula- } \\
\text { tion }\end{array}$ & $\begin{array}{l}\text { Measure- } \\
\text { ment }\end{array}$ & $\begin{array}{l}\text { Calcula- } \\
\text { tion }\end{array}$ \\
\hline Head & 3.66 & 3.50 & 5.53 & 6.04 & 8.61 & 9.33 \\
\hline Chest & 15.48 & 15.69 & 25.69 & 29.06 & 26.33 & 30.48 \\
\hline Abdomen & 17.13 & 16.14 & 19.43 & 22.93 & 19.43 & 23.87 \\
\hline
\end{tabular}

TABLE IX. COMPARISON OF ATTENUATION BODY C MEASUREMENTS WITH CALCULATIONS

\begin{tabular}{|l|l|l|l|l|l|l|}
\hline \multicolumn{7}{|c|}{ Body Attenuation C $(\mathrm{dB})$} \\
\hline \multirow{5}{*}{} & $\mathbf{2 2 7 5} \mathbf{M H z}$ & $\mathbf{3 1 5 0} \mathbf{M H z}$ & \multicolumn{2}{|c|}{$\mathbf{5 1 0 0} \mathbf{M H z}$} \\
\cline { 2 - 7 } & $\begin{array}{l}\text { Measure- } \\
\text { ment }\end{array}$ & $\begin{array}{l}\text { Calcula- } \\
\text { tion }\end{array}$ & $\begin{array}{l}\text { Measure- } \\
\text { ment }\end{array}$ & $\begin{array}{l}\text { Calcula- } \\
\text { tion }\end{array}$ & $\begin{array}{l}\text { Measure- } \\
\text { ment }\end{array}$ & $\begin{array}{l}\text { Calcula- } \\
\text { tion }\end{array}$ \\
\hline Head & 5.32 & 4.39 & 7.02 & 9.14 & 10.88 & 15.07 \\
\hline Chest & 15.14 & 15.09 & 28.41 & 26.81 & 28.60 & 30.23 \\
\hline Abdomen & 14.70 & 14.75 & 23.13 & 24.37 & 26.95 & 29.36 \\
\hline
\end{tabular}

From the comparison table of body attenuation of measurement results with the link budget calculations, it was found that the two results indicated the amount of adjacent attenuation and had an increasing trend of attenuation as the frequency increased. There was a difference of less than 1 to 3 $\mathrm{dB}$ in the attenuation of the link-budget calculation from the measurement results. By looking at the amount of adjacent attenuation in two different methods, it could be stated that the attenuation values of measurement results could indicate the attenuation of body tissues properly.

When compared graphically, the results were as indicated in Figures 10, 11, and 12.

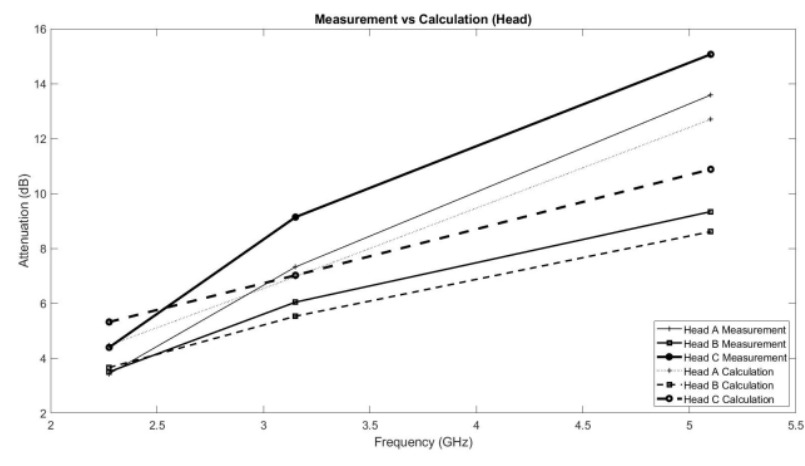

Fig. 10. Head attenuation graph of measurement and calculation results 


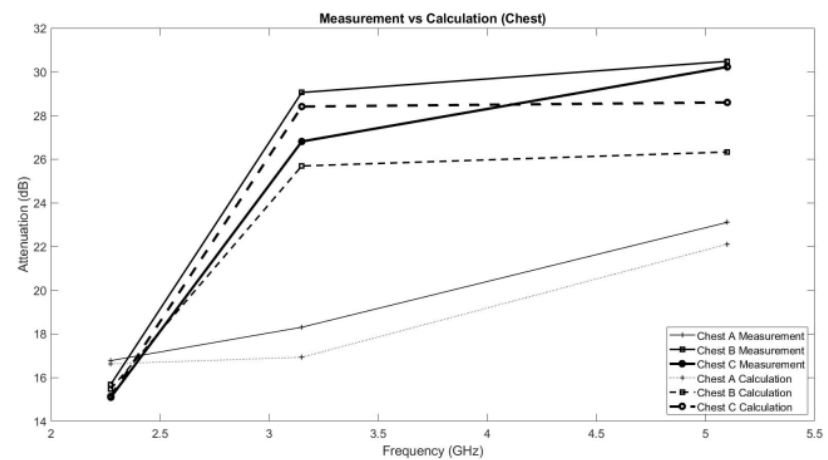

Fig. 11. Chest attenuation graph of measurement and calculation results

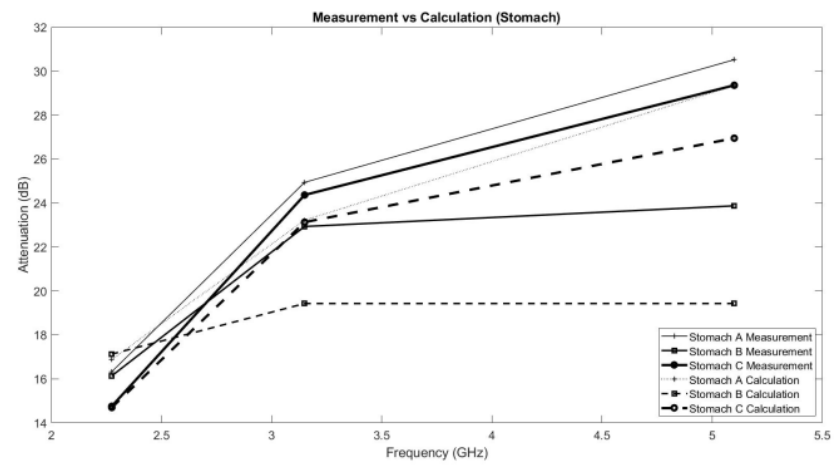

Fig. 12. Abdominal attenuation graph of measurement and calculation results

\section{SYNTHETIC}

To find the attenuation magnitude of body tissues and its characteristics on the frequency function, the magnitude response was measured in the LOS and NLOS conditions. In the LOS condition, it was found that the value of magnitude response was more significant than the magnitude response in the NLOS condition. The difference in this magnitude response was the effect of the human body between the antennas. The difference in magnitude response of LOS and NLOS was the amount of attenuation by the body tissues. It was identified that the head attenuation was smaller than that of the chest and abdomen. The amount of attenuation varied depending on each individual. Frequency also influenced the attenuation of body tissues; an increase in frequency could increase body tissues' attenuation.

At a frequency of $5 \mathrm{GHz}$, the chest and abdomen attenuation could reach $30 \mathrm{~dB}$, while the head attenuation could reach $15 \mathrm{~dB}$. This value was obtained by the human body's condition blocking the two antennas right in the middle part of the body. A link budget calculation was performed from the measurement scenario to compare the attenuation value obtained from the measurement results. The amount of body attenuation of the link budget calculations results indicated the value adjacent to the measurement result, with a difference of less than 1 to $3 \mathrm{~dB}$. This difference might be caused by minor losses in the system that were not included in the link budget calculation. The attenuation trend of the link budget calculation results also indicated an increasing trend of attenuation as the frequency increased.

Theoretically, the increase in network attenuation at the frequency function could be explained. Human body tissues have electrical properties that depend on frequency. The higher the frequency, the more conductive the body tissue would be.
For example, on the head, based on the frequency of $2 \mathrm{GHz}$, the brain conductivity for the gray matter was $1.5111 \mathrm{~S} / \mathrm{m}$, and white matter was $1.0014 \mathrm{~S} / \mathrm{m}$, while at a frequency of $5 \mathrm{GHz}$, it could reach $4.0095 \mathrm{~S} / \mathrm{m}$ and $2.8588 \mathrm{~S} / \mathrm{m}$, respectively. On the chest, for example, the lungs, at $2 \mathrm{GHz}$ of conductivity was $1.3946 \mathrm{~S} / \mathrm{m}$ and at $5 \mathrm{GHz} 3.9413 \mathrm{~S} / \mathrm{m}$.

Then, in the abdomen, there was a gastric that has a conductivity of $1.8435 \mathrm{~S} / \mathrm{m}$ at $2 \mathrm{GHz}$ and $5.1565 \mathrm{~S} / \mathrm{m}$. One more aspect that cannot be forgotten was body fluids. As commonly known, human bodies contained plenty of fluids. The body fluids had a conductivity of $2.1556 \mathrm{~S} / \mathrm{m}$ at $2 \mathrm{GHz}$ and $5.411 \mathrm{~S} / \mathrm{m}$ at $5 \mathrm{GHz}$ (C. Gabriel et al., 1996). As a result, many other body tissues affected each part of the body's attenuation that had been mentioned earlier because heterogeneous tissues made up the human body. The nature of the increase in attenuation when there was an increase in frequency could be explained by the theory of skin effect/skin depth in a conductor material. This theory explained that the higher the frequency, the smaller the electromagnetic wave's ability in the conducting material. It was due to the increase in the attenuation constant as the frequency increases.

The amount of attenuation of body tissues and their characteristics on the frequency function had been described previously. It was undoubtedly a challenge in the WBAN communication system applications such as propagation channel modeling and device design. For in-body sensors on the chest and abdomen, for example, the higher the frequency used, a device with a lower sensitivity to reception was also needed because of the considerable attenuation of body tissues at high frequencies. The human body was the medium that could cause losses in the radio wave propagation.

\section{CONCLUSIONS}

This study attempts to identify how frequency affects the attenuation of body tissues in the WBAN channel with the selected frequency range of 2-6 GHz. To obtain the attenuation data for body tissues, the magnitude response is measured at the LOS and NLOS path conditions, where the amount of attenuation is the difference in the magnitude response of the two path conditions. From the processing results of measurement data and the calculation of attenuation of body tissues, there is an effect of frequency on attenuation in all parts of the body, indicating an increasing trend of attenuation as the frequency increases. It is obtained from the results of the linear regression of attenuation data, which shows the slope value in the regression equation, which has a positive slope. From the linear regression model's test results, it is found that frequency has a more significant effect on the head attenuation than the chest and abdomen attenuation. It indicates that other variables need to be considered in modeling the attenuation equation of body tissues. Human tissues also result in different attenuation depending on the body parts. In terms of existing theories, in human tissues, the skin depth theory applies to a conductor. The higher the frequency, the smaller the skin depth will be. It results in a more significant attenuation of body tissue. Suggestions for further research include having the measurements made in the anechoic chamber to reduce the effect of multiple paths. It is also necessary to study the effect of shading or shadowing of the human body when antenna radiation is fully and partly obstructed with distance variations. 


\section{ACKNOWLEDGMENT}

This research was funded by the Department of Electrical Engineering, Faculty of Intelligent Electrical and Informatics Technology of the Institut Teknologi Sepuluh Nopember. The authors would like to extend their gratitude for this fund support.

\section{REFERENCES}

[1] Pellegrini, A. Brizzi, L. Zhang, Ali, Y. Hao, X. Wu, C C. Constantinou, Y. Nechayev, P. S. Hall, N. Chahat, M. Zhadobov, and R. Sauleau, "Antennas and Propagation for Body-Centric Wireless Communication at Milimeter-Wave Frequencies," IEEE Antennas Propagation Magazine, vol. 55, no. 4, pp. 262-287, 2013.

[2] D. B. Smith, D. Miniutti, T. A. Lamahewa, and L. W. Hanlen, "Propagation Models for Body-Area Networks:," IEEE Antennas Propagation Magazine, vol. 55, no. 5, pp. 97-117, 2013.

[3] IEEE, "IEEE Standard for Local and metropolitan area networks - Part 15.6: Wireless Body Area Network," IEEE Standards Association, New York, 2012.

[4] P. Damayanti, "Metode Interference Cancellation yang Efisien pada Jaringan Nirkabel Area Tubuh," JURNAL TEKNIK ITS, vol. 5, no. 2, 2015.

[5] A. Astrin, H.-B. Li and R. Kohno, "Standardization for Body Area Networks," IEICE Transactions, Vol. \%1 dari \%292-B, no. 10.1587/transcom.E92.B.366, pp. 366-372, 2009.

[6] H. Schwan, "Electrical Properties of Tissues and Cell Suspensions: Mechanisms and Models," dalam 16th Annual International Conference of the IEEE Engineering in Medicine and Biological Society, Baltimore.

[7] J. F. Zhao, X. M. Chen, B. D. Liang, and Q. C. Chen, "A Review on Human Body Communication: Signal Propagation Model, Communication Performance, and Experimental Issues," Wireless Communications and Mobile Computing, vol. Volume 2017, 2017.

[8] B. A. Forouzan, Data Communications and Networking, New York: McGraw-Hill, Inc., 2003.

[9] P. Bretchko and R. Ludwiq, RF Circuit Design Theory and Application, Prentice-Hall, Inc., 2000.

[10] D. C. Montgomery, E. A. Peck dan G. G. Vining, Introduction to Linear Regression Analysis, New Jersey: John Wiley \& Sons, Inc., 2012. 